\title{
Three Altemative Crops to Reduce Soil Erosion for Mountain Agriculture
}

\author{
Sewon Kim, Youngho Seo*, Jonghwan Kim, Anseok Kang, \\ Byeongchan Jeong, and Yeong-Sang Jung ${ }^{1}$ \\ Gangwon Agricultural Research \& Extension Services, Chuncheon 200-150, Korea \\ ${ }^{1}$ Kangwon National University. Chuncheon 200-701, Korea
}

\begin{abstract}
One of the problems for cultivating crops in the mountainous highland is soil erosion and nutrients runoff. Altemative cropping ways were searched to reduce soil erosion and to ensure farm income in the mountainous highland agricultural region. Three edible wild plants including goatsbeard, Korean thistle, and aster, were selected to test as altemative crops to reduce soil erosion in mountain agriculture of highland area. In the first year, the soil losses from the alternative cropping were 26 to 63 percents of the soil loss from summer radish cultivated by conservation tillage with contour and plastic film mulching. The relative soil losses in the second year ranged from 2.8 to 5.5 percents in comparison with radish cultivation. Rapid surface coverage contributed to successive soil loss protection by these alternative crops. Farm net profit of these crops was greater than that of radish. Monitoring of yields of Korean thistle or aster for further experiments, however, might be necessary for economic cultivation due to yield reduction caused by consecutive production.
\end{abstract}

Key words: Soil loss, Alternative crops, Edible perennial plants, Mountain agriculture, Highland

\section{Introduction}

Highland agriculture in the mountainous region has been mostly depended upon vegetable crop production such as Chinese cabbages and radishes ensuring high income, but involves management problems due to severe erosion. One half of the highland agricultural lands are distributed in Gangwon province (Jung et al., 1998; Jung et al., 2006). The eroded soils and runoff have caused pollution problems in running water. Muddy water caused by heavy rain in the 2006 summer growing season in the upper stream area of the Soyang River Basin in Gangwon-do, for instance, lasted for more than 9 months until late March of 2007 increasing turbidity of running water from 3.1 NTU in 2005 to 55.8 NTU in 2006 (Gangwon ARES, 2008), and thus protecting measures to reduce soil erosion are urgently needed (Jung et al., 2006; Lee et al., 2005). In addition, Jung et al. (2005) estimated total soil loss of Korea as $50 \times 10^{6} \mathrm{Mg}$ in 2004 and annual soil loss in upland in Gangwon province as $49.4 \mathrm{Mg} \mathrm{ha}^{-1}$, which is

\footnotetext{
Received : July 13. 2011 Accepted : August 16. 2011

*Corresponding author : Phone: +82332486096

E-mail: seoysh@korea.kr
}

greater than average of Korea, $37.7 \mathrm{Mg} \mathrm{ha}^{-1}$.

Based on the Revised Universal Soil Loss Equation (RUSLE), one of the most widely utilized soil loss equations, the soil loss for a given slope site is determined by rainfall and runoff erosivity $(\mathrm{R})$, soil erodibility $(\mathrm{K})$, slope length and steepness (LS), cover management (C), and support practice (P) (Renard et al., 1997). Changing the type of cultivated crops from annual vegetable crops to perennial wild crops could influence $\mathrm{C}$ factor, thus resulting in decreased soil loss. Jung et al. (1985) reported C values for several crops including maize (0.47), red pepper (0.32), sesame (0.28), upland rice (0.34), and grass (0.08). The $\mathrm{C}$ factors for soybean (Glycine max), adlay (Coix lacrymajobi L.), peanut (Arachis hypogaea), and Chinese cabbage (Brassica campestris) were reported to be 0.19, 0.18, 0.06, and 0.59, respectively (Jung et al., 2004). It should be noted that the $\mathrm{C}$ factor for Chinese cabbage, one of the major crops in mountainous highland in Gangwon province, is relatively high compared with other crops. The major reasons for the difference in $\mathrm{C}$ values among crops include crop coverage during rainy season in Korea and soil disturbance due to tillage before cultivation. Therefore it is necessary to search alternative crops to reduce soil loss.

The objective of this research was to develop an alternative 
cropping that might reduce soil erosion and could ensure farm income in this mountainous highland agricultural region. The edible wild pants could be alternative cover crops for this purpose. Three edible wild plants including goatsbeard, Korean thistles, and asters, were selected to test as alternative cropping to reduce soil erosion in mountain agriculture of highland area.

\section{Materials and Methods}

Three edible wild perennial plants including goatsbeard (Aruncus diocicus var. kamrschaticus H. Hara), Korean thistle (Cirsium setidens Nakai), and aster (Aster scaber Thunb), were selected to test as alternative crops comparing effectives with radish (Raphanus sativus) in the experimental farm located on Jawoonri, Hongcheon, Gangwon province, from 2007 to 2009 . Table 1 shows surface soil characteristics of the experimental farm.

The 8 plots with $18 \mathrm{~m}$ length and $3 \mathrm{~m}$ width were formulated on $18.5 \%$ slope, partitioned by the plastic board of $30 \mathrm{~cm}$ height. Three alternative crops, goatsbeard, Korean thistle, and aster were planted compared with radish with two replications. The goatsbeard was transplanted on May 11, 2007 at the planting density of $60-\mathrm{cm} \times 30-\mathrm{cm}$. The seedlings were grown up by seedling box. The Korean thistles and asters were transplanted at the planting density of $50-\mathrm{cm} \times 20-\mathrm{cm}$ on the same date. The seedlings were grown up by pot raising. The compost and NPK fertilizers were applied at the rate of $7 \mathrm{MT} \mathrm{ha}{ }^{-1}$ of chicken manure compost, $336 \mathrm{~kg} \mathrm{ha}^{-1}$ of nitrogen as urea, $50 \mathrm{~kg} \mathrm{ha}^{-1}$ of phosphate as super phosphate, and $276 \mathrm{~kg} \mathrm{ha}^{-1}$ of potassium as potassium chloride before transplanting. Radishes were seeded on June 5, 2007, and June 24, 2008 at the planting density of $70-\mathrm{cm} \times 25-\mathrm{cm}$ by contour planting with plastic film mulching as conventional farmers used to take to do.

Soil loss and runoff during the growing periods were monitored at each rain event in July and August, the major rainy season, by simple runoff collector (Pinson et al., 2004) installed in each plot. The amounts of soil loss and runoff were weighed in laboratory.

Surface coverage of canopy was measured indirectly through pixel analysis of photographs taken at the $2 \mathrm{~m}$ above the canopy taking green pixel number 75 to 85 being plant cover. For radish plots, $50 \%$ of surface coverage was assigned at planting because of plastic film mulching. Yields of the crops were measured after harvest.

\section{Results and Discussion}

Table 2, Table 3, and Table 4 show soil loss for the three alternative crops during the cropping period in 2007, 2008 , and 2009, respectively compared with that from radish cultivated by conservation tillage with contour cropping and plastic mulching. The cumulative soil loss from radish in 2007 was $6.0 \mathrm{Mg} \mathrm{ha}^{-1}$. The relative soil loss from the Korean thistle plot was 26 percent of that from

Table 1. Selected physico-chemical characteristics of surface soil for the experimental farm.

\begin{tabular}{|c|c|c|c|c|c|c|c|c|c|}
\hline \multirow{2}{*}{$\begin{array}{l}\mathrm{pH} \\
\left(\mathrm{H}_{2} \mathrm{O}, 1: 5\right)\end{array}$} & \multirow{2}{*}{$\begin{array}{c}\text { Electrical } \\
\text { Conductivity }\end{array}$} & \multirow{2}{*}{ Organic Matter } & \multirow{2}{*}{ Avail. $\mathrm{P}_{2} \mathrm{O}_{5}$} & \multicolumn{3}{|c|}{ Exch. Cation } & \multicolumn{3}{|c|}{ Particle Size Distribution } \\
\hline & & & & $\mathrm{Ca}$ & $\mathrm{K}$ & $\mathrm{Mg}$ & Sand & Silt & Clay \\
\hline & $\mathrm{dS} \mathrm{m}^{-1}$ & $\mathrm{~g} \mathrm{~kg}^{-1}$ & $\mathrm{mg} \mathrm{kg}^{-1}$ & \multicolumn{3}{|c|}{-------- $\mathrm{cmol}_{\mathrm{c}} \mathrm{kg}^{-1}$} & \multicolumn{3}{|c|}{--------------- \% --------------- } \\
\hline 5.5 & 0.13 & 19 & 409 & 2.9 & 0.6 & 0.8 & 59 & 25 & 16 \\
\hline
\end{tabular}

Table 2. Effect of altemative crops cultivation on soil loss in mountain agriculture in 2007.

\begin{tabular}{lcccccc}
\hline \hline Precipitation event & \multicolumn{5}{c}{ Soil loss, $\mathrm{kg} \mathrm{ha}^{-1}$} \\
\hline Date of collection & Period & Rainfall, mm & Goatsbeards & Korean thistles & Asters & Radishes \\
\hline Jul 20 & Jul 10 Jul 19 & 102 & $88 \mathrm{~b}^{\dagger}$ & $74 \mathrm{~b}$ & $136 \mathrm{a}$ & $226 \mathrm{a}$ \\
Aug 2 & Jul 24 Aug. 1 & 91 & $517 \mathrm{~b}$ & $422 \mathrm{~b}$ & $591 \mathrm{~b}$ & $1,306 \mathrm{a}$ \\
Aug 9 & Aug. 2 Aug 8 & 151 & $766 \mathrm{c}$ & $552 \mathrm{c}$ & $1,470 \mathrm{~b}$ & $2,415 \mathrm{a}$ \\
Aug11 & Aug 9 Aug 10 & 165 & $645 \mathrm{c}$ & $498 \mathrm{c}$ & $1,568 \mathrm{~b}$ & $2,066 \mathrm{a}$ \\
Cumulative & & 509 & $2,016 \mathrm{c}$ & $1,546 \mathrm{c}$ & $3,765 \mathrm{~b}$ & $6,013 \mathrm{a}$ \\
\hline Relative soil loss & & & 33.5 & 25.7 & 62.6 & 100 \\
\hline
\end{tabular}

${ }^{\dagger}$ Treatment values with same letter in each row for the same rainfall event are not significantly different at the 0.05 probability level. 
Table 3. Effect of altemative crops cultivation on soil loss in mountain agriculture in 2008 .

\begin{tabular}{lccccrr}
\hline \hline Precipitation event & \multicolumn{5}{c}{ Soil loss, $\mathrm{kg} \mathrm{ha}^{-1}$} \\
\hline Date of collection & Period & Rainfall, mm & Goatsbeards & Korean Thistles & Asters & Radishes \\
\hline Jul 21 & Jul 13 Jul 21 & 113 & $35 \mathrm{~b}^{\dagger}$ & $25 \mathrm{~b}$ & $30 \mathrm{~b}$ & $343 \mathrm{a}$ \\
Jul 26 & Jul 22 Jul 26 & 195 & $141 \mathrm{~b}$ & $185 \mathrm{~b}$ & $211 \mathrm{~b}$ & $2,923 \mathrm{a}$ \\
Aug 3 & Jul 30 Aug 3 & 63 & $138 \mathrm{~b}$ & $90 \mathrm{~b}$ & $37 \mathrm{c}$ & $2,507 \mathrm{a}$ \\
Aug 23 & Aug 9 Aug 23 & 170 & $358 \mathrm{~b}$ & $169 \mathrm{bc}$ & $75 \mathrm{c}$ & $6,496 \mathrm{a}$ \\
Cumulative & & 541 & $672 \mathrm{~b}$ & $469 \mathrm{~b}$ & $354 \mathrm{~b}$ & $12,269 \mathrm{a}$ \\
\hline Relative soil loss & & & 5.5 & 3.9 & 2.8 & 100 \\
\hline
\end{tabular}

${ }^{\dagger}$ Treatment values with same letter in each row for the same rainfall event are not significantly different at the 0.05 probability level.

Table 4. Effect of altemative crops cultivation on soil loss in mountain agriculture in 2009.

\begin{tabular}{lcccccc}
\hline \hline Precipitation event & \multicolumn{5}{c}{ Soil loss, kg ha ${ }^{-1}$} \\
\hline Date of collection & Period & Rainfall, mm & Goatsbeards & Korean Thistles & Asters & Radishes \\
\hline Jul 10 & Jul 1 Jul 9 & 238 & $439 \mathrm{~b}^{\dagger}$ & nd $^{\ddagger}$ & $253 \mathrm{~b}$ & $36,001 \mathrm{a}$ \\
Jul 16 & Jul 11 Jul 15 & 353 & $1,735 \mathrm{~b}$ & nd & $1,463 \mathrm{~b}$ & $25,798 \mathrm{a}$ \\
Jul 27 & Jul 17 Jul 26 & 154 & $267 \mathrm{~b}$ & nd & $289 \mathrm{~b}$ & $9,324 \mathrm{a}$ \\
Aug 13 & Aug 7 Aug 12 & 177 & $64 \mathrm{~b}$ & nd & $56 \mathrm{~b}$ & $5,433 \mathrm{a}$ \\
Cumulative & & 922 & $2,505 \mathrm{~b}$ & nd & $2,061 \mathrm{~b}$ & $76,556 \mathrm{a}$ \\
\hline Relative soil loss & & & 3.3 & nd & 2.7 & 100 \\
\hline
\end{tabular}

${ }^{\dagger}$ Treatment values with same letter in each row for the same rainfall event are not significantly different at the 0.05 probability level. "nd : not determined.
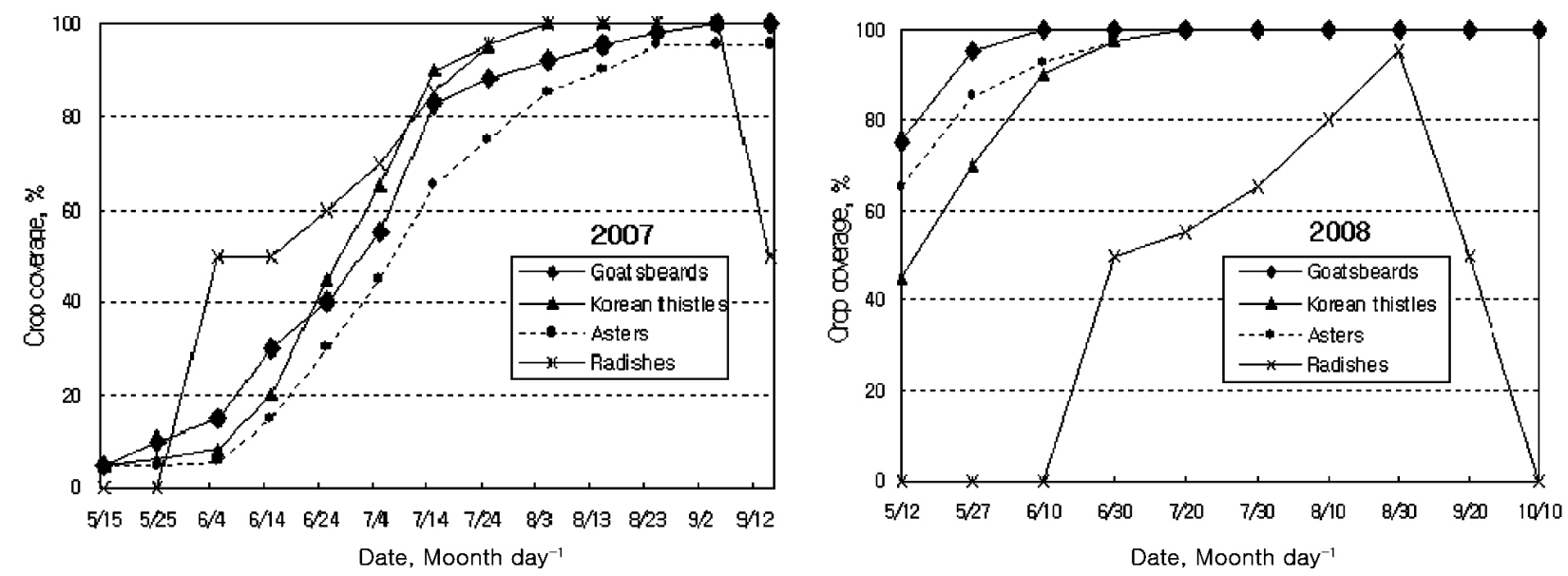

Fig. 1. Changes in crop coverage during the cropping period in 2007 (left) and 2008 (right).

radish plots, 34 percent from goatsbeard plots, and 63 percent from aster plots. The cumulative soil loss from radish in 2008 was $12.3 \mathrm{Mg} \mathrm{ha}^{-1}$. The relative soil loss from the Korean thistle, goatsbeard, and aster ranged from 2.8 to 5.5 percents of the soil loss from radish cultivation. No soil disturbance by tillage in spring and increased crop coverage at the initial growth stage for the three wild crops could result in the greater effect on soil loss reduction compared with the first year. Jung et al. (1985) reported that soil loss from grassland, tall fescue, was $67 \mathrm{Mg} \mathrm{ha}^{-1}$ in the first year, comparable to $108 \mathrm{Mg}$ ha $^{-1}$ for maize and 64 $\mathrm{Mg} \mathrm{ha}^{-1}$ for upland rice, but greatly reduced in the second year $\left(4 \mathrm{Mg} \mathrm{ha}^{-1}\right)$. The cumulative soil loss from radish in 2009 was $76.6 \mathrm{Mg} \mathrm{ha}^{-1}$, greater than the previous years. The relative soil loss from goatsbeard and aster was 3.3 and 2.7 percent of the soil loss for radish, respectively. No tillage for the three wild crops can decrease sediment loss in sloping fields (Johnson et al., 1979; Soileau et al., 1994).

Changes in crop coverage (Fig. 1) show the surface crop coverage in 2007 and 2008. Changes in crop coverage in 
Table 5. Fresh yields of the crops and their economic value.

\begin{tabular}{|c|c|c|c|c|c|c|c|c|}
\hline \multirow{2}{*}{ Crop } & \multicolumn{4}{|c|}{ Yield, $\mathrm{Mg} \mathrm{ha}^{-1} \mathrm{fw}$} & \multicolumn{4}{|c|}{ Farm profit, x 1000 US\$ } \\
\hline & 2007 & 2008 & 2009 & Average & 2007 & 2008 & 2009 & Average \\
\hline Goatsbeards & - & 4.2 & 4.6 & 4.4 & $-7.7^{\dagger}$ & 22.3 & 24.6 & 13.1 \\
\hline Korean thistles & 14.5 & 16.0 & 6.3 & 12.2 & 14.6 & 23.4 & 6.5 & 14.8 \\
\hline Asters & 4.7 & 11.8 & 11.1 & 9.2 & $-3.4^{\ddagger}$ & 16.3 & 15.1 & 9.3 \\
\hline Radishes & 41.9 & 41.9 & 43.8 & 42.5 & 9.3 & 8.4 & 5.0 & 7.5 \\
\hline
\end{tabular}

${ }^{\dagger}$ Cost alone due to no crop yield.

${ }^{\ddagger}$ Greater cost than income.

2009 showed the similar pattern to the changes in 2008 . Crop coverage of the three alternative crops increased rapidly as plant stands expanded even in the first year of cultivation. Since these alternative crops were perennial plants, the surface coverage in 2008, the second year of cultivation, so rapidly increased to over 80 percent before heavy rainy season begun, and reached almost 100 percent in July. This successful coverage reduced soil erosion by 95 percent. Goatsbeard showed the most successful coverage. Cho et al. (2010) reported that vegetation coverage was highly correlated with soil loss. In addition to crop coverage, the root growth of goatsbeard showed vigorous, resulting in effective capture of soil particles and enhanced soil erosion protection.

Table 5 shows yield of three alternative crops, and their net profit from cultivating the crops in comparison with summer radish. Average yield of goatsbeard was $4.4 \mathrm{Mg}$ $\mathrm{ha}^{-1}$, and the farm net profit was 13.1 thousand US\$ ha ${ }^{-1}$. No economic value of yield was observed in the first year of cultivation. The average farm net profit of Korean thistle and aster for three years was 14.8 and 9.3 thousand US\$ $\mathrm{ha}^{-1}$, respectively. These values were greater than that of the summer radish. The yield of Korean thistle, however, substantially decreased from $16.0 \mathrm{Mg} \mathrm{ha}^{-1}$ in the second year to $6.3 \mathrm{Mg} \mathrm{ha}^{-1}$ in the third year. Therefore, three year rotation would be necessary for the crop.

\section{Conclusion}

Three perennial wild edible plants including goatsbeards, Korean thistles, and asters could be cultivated as alternative crops to reduce soil loss from the mountain agricultural area in highland of Korea. The soil losses from these alternative plants were 26 to 63 percents of the soil loss from summer radishes cultivated by conservation tillage with contour and plastic film mulching. The relative soil losses in the second year ranged from 2.8 to 5.5 percents in comparison with radish cultivation. Successive soil loss protection by these alternative crops was due to rapid surface coverage. Farm income values of these crops were higher than that of radish. However, three year rotation might be necessary for economic cultivation of Korean thistles due to decrease in yield caused by consecutive production.

\section{References}

Cho, H.R., S.K. Ha, S.H. Hyun, S.O. Hur, K.H. Han, S.Y. Hong, S.H. Jeon, E.J. Kim, and D.S. Lee. 2010. Effect of red pepper canopy coverages on soil loss and runoff from sloped land with different transplanting dates. Korean J. Soil Sci. Fert. 43:260-267. Gangwon ARES. 2008. Preparation Plan for Synthesized Research to Develop Soil Erosion Control Technology. Gangwon Agricultural Research \& Extension Services. Korean pp. 16.

Johnson, H.P., J.L. Baker, W.D. Sharder, and J.M. Laflen. 1979. Tillage system effects on sediment and nutrients in runoff from small watersheds. Trans. ASAE 22:1110-1114.

Jung, K.H., W.T. Kim, S.O. Hur, S.K. Ha, P.K. Jung, and Y.S. Jung. 2004. USLE/RUSLE factors for national scale soil loss estimation based on the digital detailed soil map. Korean J. Soil Sci. Fert. 37:199-206.

Jung, K.H., Y.K. Sonn, S.Y. Hong, S.O. Hur, and S.K. Ha. 2005. Assessment of national soil loss and potential erosion area using the digital detailed soil maps. Korean J. Soil Sci. Fert. 38:59-65.

Jung, P.K., M.H. Ko, and K.T. Um. 1985. Discussion of cropping management factor for estimating soil loss. Korean J. Soil Sci. Fert. 18:7-13.

Jung, Y.S., J.E. Yang, C.S. Park, Y.G. Kwon, and Y.K. Joo. 1998. Changes of stream water quality and load of $\mathrm{N}$ and $\mathrm{P}$ from the agricultural watershed of the Yulmun tributary of the Buk-Han River Basin. Korean J. Soil Sci. Fert. 31:170-176.

Jung, Y.S., J.E. Yang, J.H. Joo, H.J. Shin, and S.W. Hwang. 2006. Report on Survey for Non-Point Source Pollution from Highland Agriculture. Department of Environment, Korea. pp. 504.

Lee, J.T., G.J. Lee, C.S. Park, S.W. Hwang, and Y.R. Yeoung. 
2005. Effect of hairy vetch (Vicia villosa Roth) sod culture on decreasing soil loss and providing nitrogen for Chinese cabbage in highland. Korean J. Soil Sci. Fert. 38:294-300.

Pinson, W.T., D.C. Yoder, J.R. Buchanan, W.C. Wright, and J.B. Wilkerson. 2004. Design and evaluation of an improved flow divider for sampling runoff plots. Applied Eng. in Agric. 20: 433-438.

Renard, K.G., G.R. Foster, G.A. Weesies, D.K. McCool, and D.C.
Yoder. 1997. Predicting Soil Erosion by Water: A Guide to Conservation Planning with the Revised Universal Soil Loss Equation (RUSLE). USDA Agriculture Handbook No. 703. Washington, D.C., USDA.

Soileau, J.M., J.T. Touchton, B.F. Hajek, and K.H. Yoo. 1994. Sediment, nitrogen, and phosphorus runoff with conventionaland conservation-tillage cotton in a small watershed. J. Soil and Water Cons. 49:82-89. 